\section{Kardiológia}

\section{Preferenciák és választási lehetôségek a pitvarfibrilláló betegek stroke-prevenciójában (Values and preferences of physicians and patients with nonvalvular atrial fibrillation who receive oral anticoagulation therapy for stroke prevention) Andrade JG, Krahn AD, Skanes AC, et al. (Department of Medicine, Montreal Heart Institute, Université de Montréal, Montreal, Quebec, Kanada; e-mail: Jason.guy.andrade@umontreal.ca):} Can J Cardiol. 2016; 32: 747-753.

Kanadai kérdőíves felmérésben orális alvadásgátlót szedő betegeknek és kezelőorvosaiknak a terápiával kapcsolatos preferenciáit vizsgálták a szerzők. Az összesített elemzésben a betegek a gyógyszernek az étrenddel és más gyógyszerekkel való interakcióját, a kezelőorvosok a major veszélyét tették az első helyre. A betegek terápiahưsége szempontjából fontosnak bizonyult a napi egyszeri adagolás.

Konklúzióként javasolható, hogy az antikoaguláns terápiát a szakmai ajánlások mentén a beteg állapota, kísérő betegségei, illetve igényei és preferenciái szerint írjuk elő, hogy az így javuló terápiahûség kedvező hatásai - a lehető legkedvezőbb mellékhatásprofiljai - minél több betegünknél jelentkezzenek is a stroke-prevenció területén.

Fischer Tamás dr.

\section{Pulmonológia}

Tartós hatású hörgőtágítók együttadása COPD-ben és a cardiovascularis mellékhatások veszélye (Concurrent use of long-acting bronchodilators in COPD and the risk of adverse cardiovascular events) Suissa S, Dell' Aniello S, Ernst P. (Centre for Clinical Epidemiology, Jewish General Hospital, 3755 Côte Ste-Catherine, H-461, Montréal, Québec, Kanada H3T 1E2; e-mail: samy.suissa@mcgill.ca): Eur Respir J. 2017; 49: 1602245.

A tartós hatású inhalációs béta-2-agonisták és antikolinerg szerek COPD-ben (krónikus obstruktív tüdőbetegség) első vonalbe- li gyógyszerekként ajánlottak. Az utóbbi években igazolták, hogy kombinációban hatásuk legalábbis additív. Monoterápiában való alkalmazásukra vonatkozó vizsgálatok során felvetődött esetleges cardiovascularis mellékhatásuk. Feltételezhetô, hogy ha a hatásuk összeadódik, akkor kombinációban a mellékhatás veszélye is nagyobb. Jelen cikk erre a kérdésre vonatkozó adatbázis-feldolgozást ismertet. Ez az első, a kombinált alkalmazás cardiovascularis biztonságosságára vonatkozó közlés. A szerzők Nagy-Britannia Clinical Practice Research Datalink adatbázisának 600 alapellátási praxisra vonatkozó részéből dolgoztak. A vizsgálatban 2001. augusztus 31. és 2002. augusztus 31. közötti, újonnan elkezdett tartós hatású, inhalációs adrenerg és tiotropiumkezeléseket vettek figyelembe. Új elkezdésnek vették, ha a beteg a megelőző két évben nem kapta a gyógyszert. Kiválasztottak 31138 beteget, akiknél kombinált kezelés kezdődött (az addigi monoterápiához hozzáadták a másik szert) és 31138 kontrollt, akiknél hörgőtágító monoterápia folytatódott. Azonosítottak mintegy 500 befolyásoló tényezőt, és a kiválasztást úgy végezték, hogy ezek a tényezők a két csoportban kiegyensúlyozottak legyenek. Ilyenek voltak többek között az életkor, a nem, a testtömegindex, a dohányzás, az alkohol és egyéb gyógyszerek. Kigyújtötték az egyéves követési idő alatt regisztrált szívinfarktus-, stroke-, szívelégtelenség- és arrhythmiaeseteket.

Többféle statisztikai számítást végeztek. A feldolgozás eredménye szerint szívinfarktusra a monoterápiához viszonyított kombinált terápia rizikóhányadosa 1,12 (95\% CI 0,92-1,36), stroke-ra $0,87(0,69-$ $1,10)$, arrhythmiára $1,05 \quad(0,81-1,36)$. Ezek nem szignifikánsak. Az antikolinerg szerek szupprimálhatják a cardiovascularis paraszimpatikus szabályozást, az adrenergek pedig stimulálják a szimpatikus tónust. Emiatt elméletileg számítani lehet tachyarrhythmia vagy coronariaelégtelenség felléptére. Jelen vizsgálat ezt nem erősítette meg kombinált adásuk esetén. A szívelégtelenség veszélye azonban nagyobb volt: 1,16 (1,03-1,30). Ez mérsékelt, 16\%-os rizikóemelkedés. Felvetik a lehetőséget, hogy az ok korábban nem diagnosztizált, már kezdetben is fennálló szívelégtelenség. Ennek ellene szól, hogy a szívelégtelenség zömét nem a kombinált kezelés kezdetén, csak később regisztrálták. Az induláskor szívelégtelenség diagnózis a populáció 3\%ánál szerepelt. Ha ezeket kihagyták, akkor a kockázatnövekedés 23\%-nak bizonyult. Ugyancsak érdekes, hogy gyakoribb volt akkor, ha a tiotropium-monoterápiához adták a tartós hatású adrenerg szert, mintha fordítva jártak volna el. A kérdés további vizsgálatokat igényel: A COPD mely alcsoportjai veszélyeztetettek, a társuló szívbetegség pontosabb meghatározása, redukált vagy megtartott ejekciós frakciójú-e a szívelégtelenség, társul-e például diabetes, milyen súlyosságú a légzésfunkció-károsodás stb. Erre adatbázis-feldolgozás nem alkalmas, tartós, követéses vizsgálatra van szükség.

Nagy László Béla dr.

\section{Sportorvostan}

Fizikai aktivitás mindenkinek random, csoportos próbálkozás (The phyisical activity 4 everyone cluster randomized trial: 2-year outcomes of a school physical activity intervention among adolescents) Sutherland RL, Campbell EM, Lubans DR, et al. (Hunter New England Population Health, Locked Bag No. 10,

Wallsend, New South Wales 2287, Ausztrália; e-mail: rachel.sutherland@hnehealth.nsw.gov. au): Am J Prev Med. 2016; 5: 195-205.

A serdülőknek csupán az egyötöde teljesíti az ajánlott heti ötször egyórás közepes-intenzív testmozgást - ennek mértéke is a korosodással évről évre csökken. Ezért a WHO Health Promoting School framework figyelembevételével (az iskola lehetőségei, a környezet, partnerségek) szociális kognitív és szociálökológiai elvek alapján a 12 évesek (7. osztályosok) számára a napi mozgásmennyiség fokozására 24 hónapon át tartó, többkomponensû programot szerveztek. Az oktatási stratégiákkal a minél jobb idôkihasználást keresték a mozgásra. A diákok a testnevelési órákon egyéni feladatokat is kaptak; az iskolai sportolás során az élethosszig fenntartható mozgásokat, fitneszt is tanítottak. Átalakították az iskolai politikát: az iskolai szünetnapokon is volt lehetőség sportolásra az iskolában. Szerveztek-indítottak mozgásprogramokat a közösségben is; a szülőket is próbálták minél jobban bevonni.

$\mathrm{Az}$ aktivitást akcelerométerrel (Actigraphh GT3X) hét napon át regisztrálták. Rögzítették az összes beütésszám mellett az intenzív és kevésbé intenzív időszakaszokat a kezdetkor, egy és két év után. Tíz iskola 1150 tanulójának - a fele leány volt - 
adatai, akiknek legalább három napon át volt megbízható akcelerométer-regisztrátuma, a második év végére 985-re csökkent.

$\mathrm{Az}$ első évben nem változott jelentősen a hétnapos mozgásmennyiség, de a két év elteltével a fiúk 7\%-kal - szignifikánsan több időt szántak a megfelelő mozgásmennyiségre és intenzitásra, míg a lányok nem mozogtak kevesebbet - holott a kontrollok mozgásmennyisége csökkent. (Költ- séghatékonysági adatot nem közöltek, a fiatalok fittségének alakulásáról nincs információ.)

Apor Péter dr.

\title{
MEGHÍ Vó
}

\section{ROMHÁNYI ORVOSTALÁLKOZÓ Lelkigyakorlat (manreza) orvosoknak Helyszín: SZÁR - Római katolikus templom Időpont: 2017. szeptember 2.}

\section{Fontos információk!}

\author{
Részvételi szándékát szíveskedjék augusztus 20 -ig jelezni \\ Koltayné Bartha Magdánál a 06-70/350-2062 telefonszámon vagy \\ a baratikor.saar@gmail.com e-mail címen.
}

Kérjük, hogy amennyiben lehetősége van rá, támogassa rendezvényünket a Szár Község Német Kisebbségi Oktatásáért és Kultúrájáert Egyesület (UniCredit Bank 10918001-00000036-60180000) részére átutalt vagy a helyszínen kapható csekken befizetett összeggel, „Romhányi Orvostalálkozó” megjegyzéssel.

\section{Program:}

9:00 Szentmise

10:00 Üdvözlések

Moharos Péter, polgármester

Prof. Dr. Kellermayer Miklós: Titkok bizonyossága a tudomány csúcsa

10:30 Udvardy György pécsi megyéspüspök: Egészség, ember, megváltás

11:00 Dr. Derényi Gábor, (a MOK FMSz elnöke): Az igaz példa

11:30 Prof. Dr. Szelényi Zoltán: Johann Sebastian Bach lutheránus miséiröl a Reformáció jubileuma jegyében

14:00 Prof. Dr. Matolcsy András: A patológia oktatásának kihívásai a 21. században - Romhányi professzor nyomdokában

14:30 Prof. Dr. Csókay András: Idegsebészet és hétköznapi misztika

15:00 Prof. Dr. Kerpel-Fronius Sándor: Klinikai vizsgáló csoportokban együttmüködő nem orvos képzettségü kutatók etikai felelőssége

15:30 Prof. Dr. Pintér András: Hippocrates vagy Taigetos: etikai dilemmák az újszülött-sebészetben

Moderátor: Szelényi Zoltán egyetemi tanár, emeritus professzor 


\section{Az OH 2017/26. számában megjelent kvíz megoldásai:}

1. D, 2. B, 3. D, 4. D, 5. D, 6. C, 7. C, 8. B, 9. A, 10. B

\section{Indoklások:}

1. D) A cryoglobulinaemia egyik leggyakoribb tünete a Meltzer-triász: purpura, arthralgia, myalgia. A cryoglobulinaemia következménye lehet, de nem része a Meltzer-triásznak a glomerulonephritis, a perifériás neuropathia, valamint a lymphoproliferativ betegségek.

2. B) A kemoterápia és a sugárkezelés is férfi meddőséghez vezetnek. A hereszövet kifejezetten érzékeny a sugárkezelésre, különösen a germinális sejtek, 4 Gy-nél nagyobb dózis visszafordíthatatlanul károsítja a csírasejteket, a Leydig-sejtek 20 Gy felett károsodnak.

3. D) A hirtelen testi változásokra a környezet gyakran előbb reflektál, mint ahogy azok a serdülő számára élményszinten integrálhatóvá válnának. A praepubertas korú lányoknál a testtel való elégedetlenség 40-50\%-ra tehető, a kora serdülőkorban ez az arány már $70 \%$ feletti.

4. D) Glükózmonitorozó sejteket számos helyen leírtak, glükózszenzitív és glükózreceptor-neuronok lehetnek: lateralis hypothalamus area, ventromedialis hypothalamusmag, nucleus tractus solitarii, area postrema, amygdala, globus pallidus, nucleus acumbens, valamint a praefrontalis kéreg.

5. D) A kóros tápláltsági állapot tovább növeli a morbiditás arányát, az infekciók gyakoriságát, a kór- házi tartózkodás hosszát, kemoterápia esetén a toxicitás súlyosságát, és csökkenti az életminőséget.

6. C) A paragangliomák lehetnek sporadikusak (10$20 \%$ ), illetve familiáris halmozott formák (8090\%). A sporadikus paragangliomák nőkben gyakrabban fordulnak elő, panaszokat általában a 40-70-es években okoznak. A familiáris forma férfiakban gyakoribb, és gyakran jár együtt I-es típusú neurofibromatosissal. A paragangliomák 3-4\%-a termel vazoaktív peptideket, ketacholaminokat.

7. C) A szívelégtelen betegek életminőségét a Minnesota Living with Heart Falure (MLHFQ) méri.

8. B) A borderline személyiségzavar előfordulása növekvő tendenciát mutat, a járóbetegek, tipikusan fiatal nőbetegek 15-25\%-át érinti, akik az identitásérzet, az önszabályozás és az interperszonális kapcsolatok problémáival küzdenek.

9. A) A WHO $5 \mathrm{~g}$ só bevitelét ajánlja. A sóbevitel arányos az energiabevitellel. A becsült sóbevitel a legalacsonyabb Németországban: 6,3 g.

10. B) A McKittrick-Wheelock-szindróma a vastagbél villosus adenomája által előidézett szekretoros hasmenés, dehidráció, súlyos elektrolitzavar, amely hyponatraemia, hypokalaemia, hypochloraemia képében jelenhet meg.

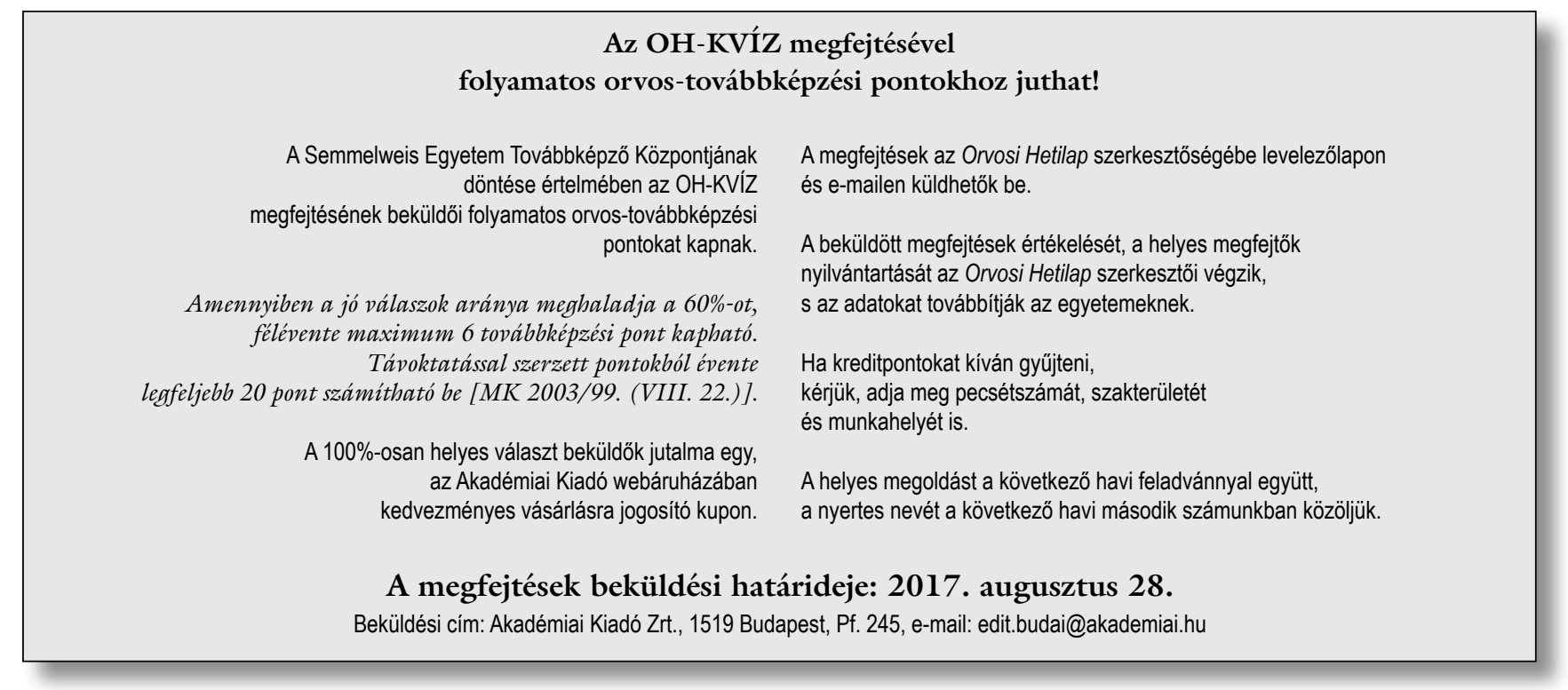




\section{OH-KVÍZ - 2017/31. szám}

Válassza ki az alábbi lehetőségek közül a megfelelót!

1. Mit mér a FABQ-H kérdőív?
A) IBD aktivitása az életminőségre.
B) Fájdalom, félelem és elkerülés kapcsolata a funk- ciókárosodással.
C) Heveny hasnyálmirigy-gyulladás és prognózisa.
D) Egyik sem.

2. Melyik kórképpel társulhat a nem alkoholos zsírmájbetegség?
A) Hypothyreosis.
B) Polycystás ovarium szindróma.
C) Mindkettő.
D) Egyik sem.

3. Mekkora az allergiás nátha prevalenciája hazánkban?
A) $25 \%$.
B) $5 \%$.
C) $35 \%$.
D) $60 \%$.

4. A lakosság hány százalékát érinti a szociális szorongás?
A) $5-6 \%$.
B) $13-15 \%$.
C) $17-20 \%$.
D) $22-25 \%$.

5. Az OTÁP2014 felmérése alapján mekkora a férfiak napi átlagos vasbevitele?
A) $9,6 \mathrm{mg}$.
B) $9,9 \mathrm{mg}$.
C) $10,2 \mathrm{mg}$.
D) $12,1 \mathrm{mg}$.

6. Melyik nem major kritériuma a polycythaemia verának?
A) Emelkedett keringő vérvolumen.
B) Csontvelő-biopszia jellegzetes képe.
C) JAK2 $2^{\mathrm{V} 617 \mathrm{~F}}$ - vagy exon-12-mutáció kimutatása.
D) Alacsony szérumeritropoetin-szint.

7. Melyik ételnek a legnagyobb a kalciumtartalma (mg/l00 g-ban kifejezve)?
A) Tojás.
B) Folyami rák.
C) Olajbogyó.
D) Konzerv szardínia.

8. Hányszorosára növeli a kóros tápláltsági mutató az obstruktív alvási apnoe kialakulásának valószínúségét?
A) Háromszorosra.
B) Négyszeresre.
C) Ötszörösre.
D) Hatszorosra.

9. Mikor javasolható a perifériáról bevezetett centrális vénás katéter alkalmazása?
A) Hiperozmoláris infúzió alkalmazásakor.
B) Véralvadási zavarban szenvedő betegnél.
C) Ha egyéb centrális vénás elérési út kontraindi- kált (például mellkasi, nyaki nyílt sérülés).
D) Mindegyik.

10. Melyik a leggyakoribb gyermekkori daganat?
A) Leukaemia.
B) Agyi tumorok.
C) Lymphomák.
D) Csontdaganatok.

Az Orvosi Hetilap egyes számai megvásárolhatók a Mediprint Orvosi Könyvesboltban.

Cím: Budapest V., Múzeum krt. 17. - Telefon: 317-4948 